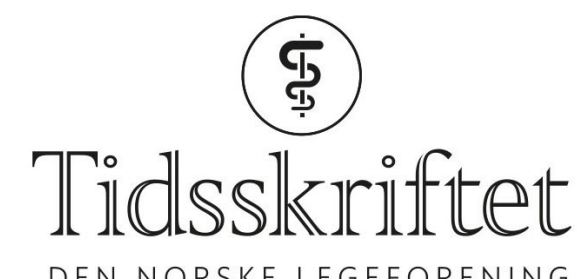

DEN NORSKE LEGEFORENING

\title{
Den uheldige treenigheten
}

RETTELSE

GEIR W. JACOBSEN

Tidsskr Nor Legeforen 2018. doi: 10.4045/tidsskr.18.0231.

I Tidsskriftet nr. 6/2018 s. 511 skal det i 2. avsnitt linje 15 og i 7. avsnitt linje 3 stå: spinal muskelatrofi.

Vi beklager feilen, den er rettet på nett.

Publisert: 17. april 2018. Tidsskr Nor Legeforen. DOI:10.4045/tidsskr.18.0276

(C) Tidsskrift for Den norske legeforening 2020. Lastet ned fra tidsskriftet.no 